\title{
INSTITUTINAL SUPPORT \\ IN THE FIELD \\ OF ANIMAL HUSBANDRY DEVELOPMENT INŠTITUCIONÁLNA PODPORA V OBLASTI ROZVOJA CHOVATELSTVA*
}

\author{
Tomáš MALATINEC**
}

\section{Introduction}

Husbandry of farm and ornamental animal species can be classified as belonging to traditional activities carried out in rural environment with a long tradition. Husbandry is the path of possible economic recovery of rural areas ${ }^{(1)}$. Maintenance of the wide variety of farm and ornamental animal breeds contributes to the conservation of agro-biodiversity in rural areas, and the mentioned objective becomes a part of a considerable number of the European Union strategy papers. Animal husbandry has also potential to improve economic situation of low-income communities stemming from mutual benefits of the relationship between farm animals and people ${ }^{(2)}$. Indigenous farm and ornamental animal species raised and bred in various rural regions within the European Union represent an agrarian cultural heritage, the potential of which can be used, inter alia, in the framework

\section{Abstract (EN)}

Public institutions represent an important part of animal husbandry development policy. In terms of the Slovak Republic, production of public value in the field of animal husbandry in the field of agro-biodiversity and agrarian cultural heritage maintenance in rural areas is also entrusted to professional self-governing institutions and breeding organizations besides state institutions. Within the European perspectives, it is the ELBARN - European Livestock Breeds Ark and Rescue Net which focuses on this issue. At present, there is a need to strengthen competences of the relevant institutional network, mainly in the field of marketing and sales aid for products which are created by breeders.

\section{Keywords (EN)}

animal husbandry, rural development, institutional support, legislation

1 TANČIN, V., 2013. Chov hospodárskych zvierat v marginálnych oblastiach, 2013, 174 p. ISBN 978-80-89418-26-8.

2 BHANDARI, D.P. - WOLLEN, T.S., 2010. Development of livestock based sustainable family farms: Heifer international approach, 2010. In: Applied Animal Husbandry \& Rural Development, 2010, Volume 3, p. 11- 14, ISSN 2312-8747. of local economic activities and in connection with either rural tourism or agro-tourism as well. The achievement of economic benefits, efficient use of natural potential of the rural areas for the purposes of animal husbandry, as well as the development of animal husbandry, support of breeding of indigenous farm and ornamental animal species and the production of the public value in this field by means of an effective institutional system require adequate attention and support. Institutions represent formalized behavior and procedures with the certain level of stabilization although not uniformity ${ }^{(3)}$. If we consider animal husbandry as a possibly part of local economic development so the institutional structure and support has relevant importance. Institutional capacity in this field can be consider as a intangible economic development factor ${ }^{(4)}$. Effective institutional network and support in the field of animal husbandry can by the path to higher viability of farms. That is one of the key issues within

\section{Abstrakt (SK)}

Verejné inštitúcie predstavujú významnú súčast’ politiky podpory rozvoja chovatel'stva. V Slovenskej republike sa tvorba verejnej hodnoty na úseku chovatel'stva v oblasti zachovania agro-biodiverzity a agrárneho kultúrneho dedičstva vo vidieckych oblastiach okrem štátnych inštitúcii zveruje i záujmovej samospráve a chovatel'ským organizáciám. V rámci európskych perspektív sa uvedenou problematikou zaoberá siet' ELBARN - European Livestock Breeds Ark and Rescue Net. V súčasnosti je potrebné posilnit' kompetencie príslušnej inštitucionálnej siete predovšetkým v oblasti marketingu a podpory odbytu produktov, ktoré vytvárajú chovatelia.

\section{Klúčové slová (SK)}

chovatel'stvo, rozvoj vidieka, inštitucionálna podpora, legislatíva

(3) WEINBERGER, O., 2010. Inštitucionalizmus - Nová teória konania, práva a demokracie, 2010, 384 p. ISBN 978-80-8101260-0.

(4) HUDEC, O. et al., 2009. Podoby regionálneho a miestneho rozvoja, EkF - TUKE Košice 2009, 344 p., ISBN 978-80-5530117-4.

* The paper has been published in the Volume Proceeding: „Výzvy a perspektívy Agrárneho práva EÚ Jean Monnet Chair [CD]. Nitra: Slovak

(University of Agriculture in Nitra, p. 203. ISBN 978-80-552-1200-5.

** Technical University of Košice, Slovakia 
challenges of rural areas(5). The institutional scheme of this field is represented not only by competent national institutions or professional self-governing institutions, but also by relevant interest associations and breeding organizations. Considerable efforts are made in this field by the European Union as well. The current challenge is to set up such legislation and institutional system at both national and European levels that will effectively lead to the fulfilment of the objective of preservation of agro-biodiversity in the field of husbandry of farm and ornamental animal breeds. The legislation in this area, however, cannot be limited only to the competence corpora of individual responsible institutions, but it is also necessary to create and incorporate an effective control and sanction mechanism, efficient protection of the law related to the farm and ornamental animal breeding, as well as a legislative enshrinement of the R\&D (Research and Development) in the field of animal husbandry support and development. The aim of the present paper is to point out the current institutional network in the field of the support of the farm and ornamental animal husbandry and to identify a potential strengthening of the institutional scheme.

\section{Material and Methods}

The present paper is based on the current information related to the provision of institutional support for the animal husbandry of farm and ornamental species in the Slovak Republic with regard to the European perspectives in the given area. The aim is to bring closer the current institutional capacities in the field of animal husbandry, which we consider to be one of partial possibilities to use the natural potential of rural areas and to form their social capital. Based on the establishment of the "institutional mosaic", a certain standpoint can be adopted in terms of the effectiveness of the current animal husbandry support policy and possible "pro future" changes. We are also trying to point out the legislative aspects of the animal husbandry support by means of both the analysis of the current and effective legislation and the judicial interpretation of the issue.

\section{Results and Discussion}

The central state administration authority of the Slovak Republic in the field animal husbandry is represented by the Ministry of Agriculture and Rural Development of the SR. The Ministry of Agriculture and Rural Development of the SR was established by Act of the SNC No. 347/1990 Coll., as amended, and Act of the SNC No. 453/1992 Coll. Framework of the Ministry serving as the central state administration authority comes from $\S 9$ of Act No. 575/2001 Coll. on organization of the activities of the Government and organization of central state administration, as amended. In the context of animal husbandry and in accordance with the wording of $\S 9$ of Act No. 575/2001 Coll., organization of competences of the Ministry of Agriculture and Rural Development of the

(5) ASHLEY, C. - MAXWELL, S., 2002. Rethinking Rural Development, In: Development Policy Review, 2002, Volume 19, Issue 4, p. $395-425$, ISSN: 1467-7679.
Slovak Republic (hereinafter MADR SR) can be provided in the areas of agriculture, veterinary control, veterinary inspection and veterinary supervision, breeding supervision, fisheries or aquaculture. In the framework of the organizational structure, in particular, Agricultural Sector (Animal Production Department) and Rural Development and Direct Payment Sector can be highlighted in relation to the field of animal husbandry in question. Specialized state government having competences in the field of animal husbandry is represented by State Veterinary and Food Administration of the SR (40 territorial districts of regional veterinary and food authorities, 3 border inspection points, 4 veterinary and food institutes and 2 additional organizations) and Breeding Inspection of the SR (3 workstations). Before enumerating the interest associations in the animal husbandry area, state enterprises such as National Stud Farm Topolčianky - state enterprise, Breeding Services of the SR - state enterprise, and Turf Bratislava - state enterprise can be mentioned in relation to the institutional support for the animal husbandry development in Slovakia. With regard to further formation of the interest associations, the internal organization of the MARD SR in the field of animal husbandry coming under the Agricultural Sector can be divided into the following specialized sections (MARD SR, 2014):

$\begin{array}{ll}\text { - poultry and eggs, ratites } & \text { - horses } \\ \text { - pigs } & \text { - fur animals } \\ \text { - cattle } & \text { - pet animals } \\ \text { - milk } & \text { - veterinary medicine } \\ \text { - sheep and goats } & \text { - central register } \\ \text { - fish-aquaculture animals } \\ \text { - bees } & \text { - breeding and reproduction } \\ & \text { offarm animals }\end{array}$

Within the mentioned specialized sections, specific interest associations are further established pursuant to $\S 20 \mathrm{f}$ of the Civil Code (Act No. 40/1964 Coll., as amended), or on the basis of Act No. 83/1990 Coll. on association of citizens, as amended, or they are formed in accordance with the provisions of the Commercial Code (Act No. 513/1991 Coll., as amended. Pursuant to Act No. 194/1998 Coll. on breeding and reproduction of farm animals and amending Act No. 455/1991 Coll., on trade licensing, as amended, after the fulfilment of those conditions ( $\$ 6$ par. 1 of the mentioned Act), the breeding organizations are approved as recognized breeding organizations by the MARD SR. Such organizations are:

- Union of Poultry Breeders of Slovakia

- Association of Pig Breeders in Slovakia

- Slovak Holnstein Association

- Association of Pinzgau Cattle Breeders in Slovakia

- Association of Slovak Spotted Cattle Breeders

- Association of Beef Cattle Breeders in Slovakia

- Slovak Association of Dairy Farmers

- Slovak Dairy Association

- Association of Sheep and Goat Breeders in Slovakia

- Association of Fish Farmers in Slovakia

- Slovak Association of Beekeepers

- Association of Horse Breeders in Slovakia 
In the case of acquisition of the status of a recognized breeding organization, the organization becomes a professional self-governing institution producing the public value in the given area in accordance with the Act No. 194/1998 Coll. on breeding and reproduction of farm animals and amending the Act No. 455/1991 Coll. on trade licensing, as amended. Basic documents explicitly define competences and individual areas of activities of the recognized breeding organizations, which are related to the public interest and the provision of the public value in compliance with the relevant policy of the MARD SR. On the basis of $\S 6$ par. 1 of the Act No. 194/1998 Coll., the recognized breeding organizations are conferred the right to carry out the tasks of care and development of breeding and production specified in $\S 3$ par. ld), h), i) and j):

- defining of breeding program containing a program of breeding and production of certain species or breed of purebred farm animals, together with specified breeding aim, methods and procedures of its implementation

- keeping pedigree books

- keeping breed registers

- keeping breeding records.

Based on the given tasks in the given sections, procedural rules of the Administrative Law (Act No. 71/1967 Coll. on administrative proceeding, as amended - Administrative Code) can be applied to the activities of the recognized breeding organizations acting as professional self-governing institutions (public administration subsystem). For example, in accordance with the decision of the Supreme Court of the Slovak Republic - judgment No. 2Sdo/4/2012, such performance of the defined public tasks can be considered as professional self-government aimed at the provision of the public interest. It subsequently implies other legislative aspects related to the administrative judging within the framework of activities of the recognized breeding organizations. It is necessary to add that such organizations, or professional associations (recognized breeding organizations) are established with the participation of the Act No. 194/1998 Coll. on breeding and reproduction of farm animals and amending the Act No. 455/1991 Coll. on trade licensing, as amended, through which they are conferred the possibility to take an action in the public administration area. The objective of the activity is to serve for the benefit of society, not only of an individual.

Within the framework of the analysis of the institutional capacities in the field of animal husbandry development support, Slovak University of Agriculture cannot be omitted. Acting as an educational and research institution, it is also involved in the activities of partial areas of the animal husbandry development. Its position in the Approval Committee on Poultry, which was formed on the basis of the Act No. 194/1998 Coll. on breeding and reproduction of farm animals and amending the Act No. 455/1991 Coll. on trade licensing, as amended. The Approval Committee on Poultry represents an authority of the Ministry of Agriculture and Rural Development of the SR.

In addition to the previously mentioned institutional capacities in the field of animal husbandry support and development in the Slovak Republic, there is also a professional association of citizens named Slovak Breeder Association (hereinafter referred to as SBA), which was established in accordance with Act No. 83/1990 Coll. on association of citizens, as amended. The association is based on voluntary membership and brings together animal breeders with the aim of maintaining genetic resources of existing purebred animal breeds and species, protecting endangered animal species and creating new breeds and lower zootechnical units (Statute of the SBA, 2014). The statute also declares for the contribution to social efforts in terms of formation and protection of environment through the professional management of the organization and breeding activity. The SBA is a legal entity with legal subjectivity ( $\S 3$ of the Statute of the SBA) and the legal subjectivity may also be entitled to the lower units, which are represented by breeding clubs and regional organizations. In comparison with the previous breeding organizations, the SBA focuses largely on the development of "backyard breeding", including ornamental breeds of poultry, pigeons and birds.

In addition to the national institutional network, efforts of the European Union in this field can be mentioned within the framework of the provided analysis as well. The European Union tries to create and implement an efficient policy aimed at the maintenance and development of breeding of indigenous animal breeds in European regions. And it not only focuses on the support for the animal husbandry management and the support in the context of marketing activities in relation to products achieved by breeders, but also tries to ensure support of services necessary for those farmers. The objective is to create European Livestock Breeds Ark and Rescue Net (hereinafter ELBARN) with the purpose of maintaining and preserving biodiversity within the framework of indigenous farm animal breeds and, in this way, contributing to the preservation of the cultural heritage of the European regions. In terms of the Slovak Republic, there are six breeds registered within the ELBARN network:

$\begin{array}{ll}\text { - } \text { sheep } & \text { - CIGAJA } \\ \text { - pouts } & \text { - BROWN SHORTHAIR GOAT } \\ \text { - cattle } & \text { - ORAVKA } \\ & \text { - SLOVAK SPOTTED } \\ \text { - pigs } & \text { - SLOVAK PINZGAU } \\ & \text { - SLOVAK BLACK-SPOTTED }\end{array}$

Formation of this support and rescue network was a project initiative involving Council Regulation EC/870/2004 establishing a Community programme on the conservation, characterization, collection and utilization of genetic resources in agriculture. According to the introductory provisions of the mentioned regulation, the European Union considers that the biological and genetic diversity of agriculture is important for the sustainable development of agricultural production and rural areas. The steps made in the given area contribute to the fulfilment of resolutions and objectives within the framework of the Convention on Biological Diversity and Community Biodiversity Strategy . Effective institutional support in this field contributes to the fulfilment of the expected objectives just for the above-mentioned reasons. If the ambition of either European or national development policies is to initiate the development and the use of the potential of 
rural areas, animal husbandry and its promotion should occupy a stable place in programming of such policies.

There were 33,810 active farms, including 32,920 farm animal breeding farms, registered in the Slovak Republic at 30 April 2014. In comparison with the situation at 31 March 2014, 0.35 percent increase has been recorded. The comparison of the statistically processed data of the latest months (May and April 2014) also demonstrates a slight increase in the number of farm animals. The most significant increase occurred in the case of ratites $(2.40 \%)$ and poultry $(2.02 \%)$. Even the above-mentioned implies the need for properly set institutional capacities in terms of the animal husbandry development support that would also carry out and cover the competences with the public interest within the meaning of the biodiversity and agrarian cultural heritage maintenance. In terms of the Slovak Republic, they are currently standing at the beginning of an ambitious challenge of an effective and, in particular, efficient support for both breeders and achievement of the public value in this field.

\section{Conclusion}

Institutional support occupies an important place within the policy of the animal husbandry support and maintenance of the agrarian heritage of rural areas. Animal husbandry has potential contributes to recovery of rural areas. With regard to animal species registered in the ELBARN network belonging to Slovak indigenous species, it is obvious that Slovakia has potential in this area. Creation of an effective institutional network and support contributes to the animal husbandry development. In terms of the Slovak Republic, a positive milestone is represented by cooperation between state authorities and the professional self-government within the breeding organizations through delegated powers. However, the attention of the state institutions should be concentrated not only on the maintenance of the diversity of the breeds, but also on the marketing support and sales aid for the breeders. Recognized breeding organizations forming the public value in the field of animal husbandry are established with the participation of Act No. 194/1998 Coll. on breeding and reproduction of farm animals and amending Act No. 455/1991 Coll. on trade licensing, as amended, in compliance with which they are conferred certain powers in the area of implementation of the tasks related to the care and development of breeding and production. The "pro future" suggestions can be complemented with strengthening of the competence corpus of relevant public institutions in the area of marketing support and sales aid policies of breeders, as well as with the implementation of control mechanisms ensuring supervision over breeding of indigenous species aimed at defining current problems and needs of breeders and, in this way, partially contributing to the development of rural areas. Respective development strategies in this field should meet the needs of breeders and to strengthen an institutional capacity and control mechanism within the animal husbandry field just because creation of the public values declared by legislation.

\section{References}

1. ASHLEY, C. - MAXWELL, S., 2002. Rethinking Rural Development, In: Development Policy Review, 2002, Volume 19, Issue 4, p. 395 - 425, ISSN: 1467-7679.

2. BHANDARI, D.P. - WOLLEN, T.S., 2010. Development of livestock based sustainable family farms: Heifer international approach, 2010. In: Applied Animal Husbandry \& Rural Development, 2010, Volume 3, p. 11- 14, ISSN 2312-8747.

3. ELBARN, 2009. ELBARN Guidelines. EuroNatur, 2009, 32. p. [cit. 14.05.2014] available online: www.elbarn.net.

4. ELBARN, 2009. ELBARN Book. EuroNatur, 2009, 73. p. [cit. 14.05.2014] available online: www. elbarn. net.

5. Farm Animals Central Register Review of the Farm Animals Central Register of 30 April 2014. FACR, 2014. [cit. 14.05.2014] available online: ww.pssr.sk/cehz.

6. HUDEC, O. et al., 2009. Podoby regionálneho a miestneho rozvoja, EkF - TUKE Košice 2009, 344 p., ISBN 978-80-553$0117-4$.

7. TANČIN, V., 2013. Chov hospodárskych zvierat v marginálnych oblastiach, 2013, 174 p. ISBN 978-80-89418-26-8.

8. WEINBERGER, O., 2010. Inštitucionalizmus - Nová teória konania, práva a demokracie, 2010, 384 p. ISBN 978-80-8101260-0.

\section{Legislation:}

1. Act No. 194/1998 Coll. on breeding and reproduction of farm animals and amending Act No. 455/1991 Coll. on trade licensing, as amended.

2. Act No. 83/1990 Coll. on association of citizens, as amended.

3. Council Regulation EC/870/2004 establishing a Community programme on the conservation, characterization, collection and utilization of genetic resources in agriculture.

4. Judgment of the Supreme Court No. 2Sdo/4/2012.

5. Statute of the Slovak Breeder Association (SBA).

\section{Internet Sources:}

1. www.mpsr.sk

2. www.elbarn.net

3. www.pssr.sk/cehz

\section{Contact address/ Kontaktná adresa}

Mgr. Ing. Tomáš Malatinec, PhD.

Department of Regional Science and Management, Faculty of Economics, Technical University of Košice e-mail: tomas.malatinec@tuke.sk 